\title{
Pengaruh Paket Menu Sehat terhadap Peningkatan Kadar Hb Remaja Putri
}

\author{
Purwati $^{1}$, Rohayati ${ }^{2}$ \\ Jurusan Keperawatan, Politeknik Kesehatan Tanjung Karang, Indonesia \\ Email: purwatidjamil@gmail.com
}

\begin{abstract}
The Influences of Healthy Menu to Female Teenager Hb Level Improvement. Female teenager is one of the vulnerable groups to suffer anemia. Anemia prevalence of female teenager belongs to a public health problem. The objective of this research was to find out the influences of the healthy menu to female teenager Hb level improvement in the Roudhlatul Qur'an Islamic Boarding School in Metro in 2018. This research used quasi-experiment pretest and posttest with control group design by comparing two groups with the intervention of healthy menu package administration to a treatment group and giving no treatment to control group. The population was 60 female teenagers in Roudhlatul Qur'an Islamic Boarding School. Data were collected by conducting $\mathrm{Hb}$ examination by using Haemock before and after treatment. Data were processed and analyzed by using an independent t-test. The average result of $\mathrm{Hb}$ level of respondents having health menu package treatment was $14.76 \mathrm{gr} \%$ with standard of deviation of 1.37 and $13.56 \mathrm{gr} \%$ in control group respondent with a standard of deviation of 1.05. The statistic test result derived p-value 0.000 with an alpha of 5\%, and this indicated that there was a significant difference in $\mathrm{Hb}$ level average between treatment group and control group. There is an effect of healthy menu packages on Improvement Young Women HB Levels.
\end{abstract}

Keywords: Healthy menu package, Hb level, Female teenager

\begin{abstract}
Abstrak: Pengaruh Paket Menu Sehat terhadap Peningkatan Kadar Hb Remaja Putri. Remaja putri merupakan salah satu kelompok yang rawan menderita anemia. Prevalensi anemia pada remaja putri masih cukup tinggi yang tergolong masalah kesehatan masyarakat. Tujuan penelitian ini adalah Untuk mengetahui Pengaruh Paket Menu Sehat Terhadap Peningkatan Kadar Hb Remaja Putri Pondok Pesantren Roudlatul Qur'an di Kota Metro tahun 2018. Metode penelitian ini menggunakan desain quasi experiment pre post test with control group dengan intervensi Pemberian Paket Menu Sehat yaitu membandingkan dua kelompok remaja putri dengan pemberian paket menu sehat untuk kelompok perlakuan dan tanpa perlakuan untuk kelompok kontrol. Populasi dalam penelitian ini adalah Remaja Putri Sekolah Menengah Pertama Pondok Pesantren Roudlatul Qur'an di Kota Metro. Sampel penelitian berjumlah 60 responden. Pengumpulan data dengan cara melakukan pemeriksaan $\mathrm{Hb}$ dengan menggunakan Haemocek sebelum dan sesudah perlakuan.Data diolah dan dianalisis dengan menggunkan uji $\mathrm{T}$ independent. Hasil rata rata nilai kadar $\mathrm{Hb}$ responden yang diberikan paket menu sehat adalah 14,76gr\% dengan standar deviasi 1,37, sedangkan responden yang diberikan paket menu program pondok (kelompok kontrol) rata-rata kadar Hb-nya adalah 13,56gr\% dengan standar deviasi 1,05. Hasil uji statistik didapat p-value 0,000, berarti pada alpha 5\% terdapat perbedaan yang signifikan rata-rata kadar $\mathrm{Hb}$ antara responden yang diberi paket menu sehat dengan responden yang diberikan paket menu program pondok. Ada pengaruh paket menu sehat terhadap Peningkatan Kadar Hb Remaja Putri.
\end{abstract}

Kata kunci: Paket Menu Sehat, Kadar Hb, Remaja Putri

\section{PENDAHULUAN}

Hemoglobin $(\mathrm{Hb})$ berfungsi untuk mengikat oksigen satu gram hemoglobin akan bergabung dengan $1,34 \mathrm{ml}$ oksigen.Tugas hemoglobin adalah menyerap karbon dioksida dan ion hidrogen serta membawanya keparu tempat zat tersebut dilepaskan dari hemoglobin. (Wiwik, 2008). Kadar Hb ialah ukuran pigmen respiratorik dalam butiran-butiran darah merah, jumlah $\mathrm{Hb}$ dalam darah normal adalah kira-kira 15 gram setiap $100 \mathrm{ml}$ darah dan jumlah biasanya disebut 100 persen. WHO telah menetapkan batas kadar $\mathrm{Hb}$ normal berdasarkan umur dan jenis kelamin, anak 6 bulan sampai 6 tahun batas nilai $\mathrm{Hb} 11,0 \mathrm{gr}$, anak 6 tahun sampai 14 tahun batas nilai $\mathrm{Hb} 12,0 \mathrm{gr}$, pria dewasa batas nilai $\mathrm{Hb}$ 13,0 gr (WHO). 
Menurut WHO batasan usia remaja yaitu antara umur 10-19 tahun, remaja adalah masa peralihan dari anak menuju dewasa dimana terjadi perubahan fisik, mental dan emosional secara cepat sehingga dibutuhkan makanan yang mengandung unsur gizi yang diperlukan tubuh untuk tumbuh dan berkembang. Dengan mengkonsumsi makanan yang cukup dan teratur remaja akan tumbuh sehat.

Remaja putri merupakan salah satu kelompok yang rawan menderita anemia. DiIndonesia prevalensi anemia masih cukup tinggi. Hal ini pernah ditunjukan dari data Riskesdas 2013, prevalensi anemia di Indonesia yaitu $21,7 \%$, dengan proporsi $20,6 \%$ diperkotaan dan $22,8 \%$ di pedesaan serta $18,4 \%$ laki-laki dan 23,9\% perempuan. Berdasarkan kelompok umur, penderita anemia berumur 5-14 tahun sebesar $26,4 \%$ dan sebesar $18,4 \%$ pada kelompok umur 15-24 tahun. Akibat jangka panjang anemia pada remaja putri adalah apabila nantinya hamil akan meningkatkan resiko komplikasi, resiko kematian maternal, angkaprematur dan angka kematian perinatal (Riset Kesehatan Dasar, 2013).

Remaja putri yang kurang gizi atau terlalu kurus (KEK), anemia, kekurangan kalsium, vitamin $\mathrm{D}$, yodium, seng, dan kekurangan vitamin, serta mineral lainya akan mempengaruhi proses reproduksi. Khusus remaja putri yang mengalami gangguan pertumbuhan maka akan menjadi pendek dan tulang panggulnya tidak sempurna akibatnya sulit untuk melahirkan. Remaja putri yang telah memasuki masa pubertas dan mulai menstruasi tiap bulannya lebih mudah menderita anemi dibandingkan dengan remaja putra. Wanita dan remaja putri membutuhkan zat besi dua kali lipat lebih banyak dari pada pria atau remaja putra karena mengalami haid dan banyak mengeluarkan darah waktu melahirkan (Proverawati, 2011).

Anemia merupakan kondisi dimana kurangnya sel darah merah (eritrosit) dalam sirkulasi darah atau massa hemoglobin sehingga tidak mampu memenuhi fungsinya sebagai pembawa oksigen keseluruh jaringan. Penurunan $\mathrm{Hb}$ dapat menyebabkan cepat lelah, nyeri kepala, kesulitan bernafas, palpitasi, pucat pada muka, telapak tangan, kuku dan konjungtiva (Tarwoto, 2007). Anemia selama kehamilan dapat meningkatkan risiko kematian pada saat melahirkan, melahirkan bayi dengan berat badan lahir rendah, janin dan ibu mudah terkena infeksi, keguguran, dan meningkatkan risiko bayi lahir prematur (Manuaba, 2010).

Data prasurvei terhadap 100 remaja putri di SMKN 1 Terbanggi Besar pada bulan
September 2011 diketahui sebanyak 30\% remaja putri mengalami gejala anemia (Listiana, 2016).

Hasil penelitian yang dilakukan (Sukmawati, 2011) ditemukan kejadian anemia $25,9 \%$ pada perempuan dewasa ( $\geq 15$ tahun) dan anemi pada remaja didapatkan hasil $65 \%$ dari 142 siswi SMP Negeri Kibang menderita anemia. Menurut penelitian (Martini, 2016), tentang Faktor-Faktor yang berhubungan dengan kejadian anemi pada remaja putri MAN 1 Metro didapatkan hasil penelitian diperoleh kejadian anemia berjumlah $40 \%$ dari 115 responden. Status gizi responden yang berdasarkan indikator IMT menunjukkan kategori kurus berjumlah $34,8 \%$. Hasil uji statistik menggunakan chisquare menunjukkan faktor-faktor yang berhubungan dengan anemia adalah status gizi $(p-$ value $=0,009)$, pengetahuan $(p$-value $=0,048)$, pendidikan ibu ( $p$-value $=0,036)$.

Penelitian yang dilakukan (Suryani, dkk 2016), tentang Analisis Pola Makan dan anemia gizi besi pada remaja putri kota Bengkulu didapat hasil prevalensi gizi besi pada remaja putri di Kota Bengkulu 43\%, pengetahuan remaja tentang anemia kurang $44,75 \%$ dan pola makan tidak baik sebanyak $79,25 \%$. Tidak terdapat hubungan antara pengetahuan tentang anemia dengan kejadian anemia ( $p$-value $=0,349)$ dan tidak terdapat hubungan antara pola makan dengan kejadian anemia ( $p$-value $=0,11)$.

Selain mengkonsumsi $\mathrm{Fe}, \mathrm{Hb}$ dapat ditingkatkan dengan mengkonsumsi makanan yang bersumber protein nabati dan hewani, pada protein nabati kita dapat mengkonsumsi kacangkacangan, dan sayur, sedangkan hewani dapat diberikan sumber makanan seperti daging dan telur (Bakta, 2006).

Berdasarkan hasil studi pendahuluan yang dilakukan pada remaja putri Pondok Pesantren Roudlatul Qur'an di Kota Metro terhadap 10 remaja putri yang diperiksa $\mathrm{Hb}$ diperoleh hasil sebanyak 5 remaja putri $(50 \%)$ mengalami anemia, sedangkan dari 10 remaja putri tersebut ternyata terdapat 7 remaja putri $(70 \%)$ memiliki pengetahuan yang kurang tentang anemia dan 3 $(30 \%)$ remaja putri mempunyai pengetahuan yang baik.

Berdasarkan fenomena di atas, maka peneliti tertarik untuk meneliti tentang "Pengaruh Paket Menu Sehat Terhadap Peningkatan Kadar $\mathrm{Hb}$ Remaja Putri Pondok Pesantren Roudlatul Qur'an di Kota Metro tahun 2018.

Berdasarkan latar belakang di atas, maka peneliti perlu diketahui Pengaruh Paket Menu Sehat Terhadap Peningkatan Kadar Hb Remaja Putri Pondok Pesantren Roudlatul Qur'an di Kota Metro tahun 2018. 


\section{METODE}

Metode penelitian ini menggunakan desain quasi experiment pre post test with control group dengan intervensi pemberian Paket Menu Sehat yaitu membandingkan dua kelompok remaja putri dengan pemberian paket menu sehat untuk kelompok perlakuan dan tanpa perlakuan untuk kelompok kontrol.

Populasi penelitian ini adalah Remaja Putri yang tinggal di Pondok pesantren Roudlatul Qur'an di kota Metro. Sampel penelitian remaja putri Sekolah Menengah Pertama Pondok Pesantren Roudlatul Qur'an di Kota Metro. Berdasarkan perhitungan didapatkan sejumlah 30 responden tiap kelompok, dengan perbandingan $1: 1$, sehingga keseluruhan responden sejumlah 60. Agar karakteristik sampel tidak menyimpang dari populasinya, maka sampel ditentukan dengan kriteria inklusi dan eksklusi. Analisis data yang digunakan dalam penelitian ini adalah statistik infrensial.

Penelitian ini telah mendapatkan persetujuan etik penelitian (ecthical clearance) dari Komisi Etik Penelitian Kesehatan Politeknik Kesehatan Tanjung Karang No. 225/EC/KEPTJK/VII/2018.

\section{HASIL}

Tabel 1. Distribusi Responden Berdasarkan Kadar Hb Sebelum dan Sesudah

\begin{tabular}{lrcr}
\hline \multicolumn{1}{c}{ Variabel } & $\begin{array}{c}\text { Mean } \\
\text { Median }\end{array}$ & SD & $\begin{array}{c}\text { Min- } \\
\text { Max }\end{array}$ \\
\hline Kadar Hb Sebelum & 14,21 & 1,75 & 8,8 \\
pemberian paket menu sehat & 14,35 & & 18,0 \\
\hline Kadar Hb sesudah & 14,76 & 1,37 & 9,9 \\
pemberian paket menu sehat & 14,95 & & 17,6 \\
\hline Kadar Hb Kelompok & 14,41 & 1,64 & 10,4 \\
kontrol (program pondok) & 14,45 & & 18,0 \\
Sebelum & & & \\
\hline Kadar Hb kelompok kontrol & 13,56 & 1,05 & 11,0 \\
(Program pondok) & 13,75 & & 15,4 \\
Sesudah & & & \\
\hline
\end{tabular}

Hasil analisis terlihat bahwa rata-rata kadar $\mathrm{Hb}$ responden sebelum pemberian paket menu sehat nilai mean $14,21 \mathrm{gr} \%$, dengan standar deviasi 1,75. Kadar $\mathrm{Hb}$ terendah $8,8 \mathrm{gr} \%$ dan kadar $\mathrm{Hb}$ tertinggi 18,0gr\%.

Rata-rata kadar $\mathrm{Hb}$ responden sesudah pemberian paket menu sehat nilai mean 14,76gr\% dengan standar deviasi 1,37. Kadar $\mathrm{Hb}$ terendah 9,9gr\% dan kadar $\mathrm{Hb}$ tertinggi $17,6 \mathrm{gr} \%$.

Rata-rata kadar $\mathrm{Hb}$ responden pada kelompok kontrol nilai mean 14,41gr\%, dengan standar deviasi 1,64. Kadar Hb terendah 10,4gr\% dan kadar $\mathrm{Hb}$ tertinggi 18,0gr\%.

Tabel 2. Nilai Rata-Rata Hb Responden Sebelum dan sesudah Intervensi

\begin{tabular}{|c|c|c|c|c|c|}
\hline Intervensi & Mean & SD & SE & $\begin{array}{c}p- \\
\text { value }\end{array}$ & $\mathbf{n}$ \\
\hline $\begin{array}{l}\text { Kelompok } \\
\text { Intervensi Paket }\end{array}$ & & & & \multirow{3}{*}{0,000} & \multirow{3}{*}{30} \\
\hline Menu Sehat & 14,21 & 1,75 & 0,32 & & \\
\hline $\begin{array}{l}\text { Sebelum } \\
\text { Sesudah }\end{array}$ & 14,76 & 1,37 & 0,25 & & \\
\hline Kelompok & & & & \multirow{3}{*}{0,000} & \multirow{3}{*}{30} \\
\hline $\begin{array}{l}\text { Kontrol } \\
\text { (program }\end{array}$ & 14,41 & 1,64 & $\begin{array}{l}0,30 \\
010\end{array}$ & & \\
\hline $\begin{array}{l}\text { pondok ) } \\
\text { Sebelum } \\
\text { Sesudah }\end{array}$ & 13,56 & 1,05 & & & \\
\hline
\end{tabular}

Berdasarkan tabel 2 rata rata nilai kadar $\mathrm{Hb}$ responden pada kelompok intervensi pada pengukuran pertama sebelum diberikan paket menu sehat adalah 14,21 gr\% dengan standar deviai 1,75. Pada pengukuran ke dua, setelah pemberian paket menu sehat didapat rata-rata nilai kadar $\mathrm{Hb}$ 14,76gr\% dengan standar deviasi 1,37. Hasil uji statistik didapat nilai $p$ value $=0,000$, maka dapat disimpulkan ada perbedaan nilai kadar $\mathrm{Hb}$ responden pada remaja putri di pondok pesantren Roudlatul Qur'an di Kota Metro sebelum dan sesudah pemberian paket menu sehat.

Pada kelompok kontrol rata-rata nilai kadar $\mathrm{Hb}$ responden pada pengukuran pertama untuk intervensi program pondok pesantren adalah 14,41gr\% dengan standar deviasi 1,64. Pada pengukuran ke dua, setelah pemberian program pondok pesantren didapat rata-rata nilai 13,56gr\% dengan standar deviasi 1,05. Hasil uji statistik didapat nilai $p$-value $=0,000$, maka dapat disimpulkan ada perbedaan nilai kadar $\mathrm{Hb}$ responden sebelum dan sesudah pemberian menu program pondok.

Tabel 3. Nilai Rata-Rata Hb Responden Menurut Pemberian Paket Menu

\begin{tabular}{|c|c|c|c|c|c|}
\hline Paket Menu & Mean & SD & SE & $\begin{array}{c}p- \\
\text { value }\end{array}$ & $\mathbf{n}$ \\
\hline $\begin{array}{l}\text { Paket Menu } \\
\text { Sehat }\end{array}$ & 14,76 & 1,37 & 0,25 & 0,000 & 30 \\
\hline $\begin{array}{l}\text { Paket Menu } \\
\text { progam } \\
\text { pondok }\end{array}$ & 13,56 & 1,05 & & & 30 \\
\hline
\end{tabular}

Berdasarkan tabel 3 rata rata nilai kadar $\mathrm{Hb}$ responden yang diberikan paket menu sehat adalah 14,76gr\% dengan standar deviasi 1,37, sedangkan responden yang diberikan paket menu program pondok (kelompok kontrol) rata-rata 
kadar Hb-nya adalah $13,56 \mathrm{gr} \%$ dengan standar deviasi 1,05. Hasil uji statistik didapat $p$-value 0,000 , berarti pada alpha $5 \%$ terdapat perbedaan yang signifikan rata-rata kadar $\mathrm{Hb}$ antara responden yang diberi paket menu sehat dengan responden yang diberikan paket menu program pondok.

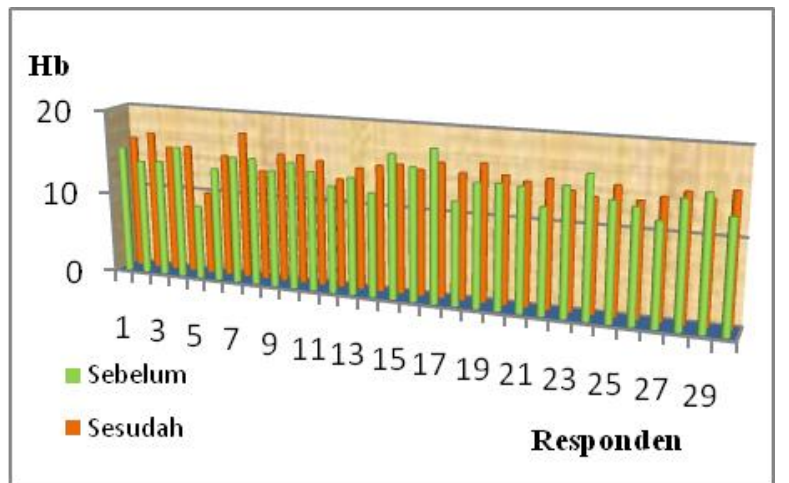

Gambar 1. Rata-Rata Kadar Hb Sebelum dan Sesudah Pemberian Paket Menu Sehat

Pada gambar histogram diatas terlihat hasil penelitian tentang pemeriksaan kadar $\mathrm{Hb}$ sebelum dan sesudah pada 30 responden terlihat hampir semua kadar $\mathrm{Hb}$ responden terjadi peningkatan kadar $\mathrm{Hb}$ rata-rata $0,45 \mathrm{gr} \%$ dengan standar deviasi 1,37.

\section{PEMBAHASAN}

\section{Rata-Rata Kadar Hb Remaja Putri Sebelum Pemberian Paket Menu Sehat}

Kadar $\mathrm{Hb}$ sebelum intervensi merupakan kadar $\mathrm{Hb}$ awal yang digunakan dalam penelitian, semua responden baik kelompok intervensi maupun kelompok kontrol dilakukan pengukuran kadar $\mathrm{Hb}$. Pemilihan responden dilakukan secara undian dan sesuai dengan kriteria.

Hasil penelitian diperoleh rata-rata kadar $\mathrm{Hb}$ remaja putri di pondok pesantren Roudlatul Qur'an dikota Metro sebelum pemberian paket menu sehat dengan mean $14,21,8,8 \mathrm{gr} \%$ untuk $\mathrm{Hb}$ terendah dan 18,0gr\% untuk $\mathrm{Hb}$ tertinggi dengan Standar Deviasi 1,75 sedangkan pada kelompok kontrol rata-rata kadar $\mathrm{Hb}$ sebelum intervensi terendah adalah $10,4 \mathrm{gr} \%$ dan tertinggi adalah $18,0 \mathrm{gr} \%$. Pada keadaan normal kadar $\mathrm{Hb}$ remaja putri usia anak 6 sampai 14 tahun adalah $12 \mathrm{gr} \%$ atau ambang batas hemoglobin usia 12-14 tahun adalah 12,0g/dl (WHO, 2001 ).

Pada masa remaja merupakan fase peralihan dari masa anak-anak menuju masa dewasa. Perkembangan yang terjadi begitu pesat selain perubahan fisik dengan bertambahnya massa otot, bertambahnya jaringan lemak dalam tubuh dan perubahan hormonal sehingga diperlukan asupan gizi yang cukup besar.

Menurut Arisman (2010) di masa peralihan remaja menjadi sangat rentan, ada tiga alasan mengapa remaja dikatagorikan rentan yaitu :

1. Percepatan pertumbuhan dan perkembangan tubuh memerlukan energi dan zat gizi yang lebih banyak.

2. Perubahan gaya hidup dan kebiasaan pangan menuntun penyesuaian masukan energi dan zat gizi.

3. Keikutsertaan dalam kegiatan olah raga, kecanduan alkohol dan obat meningkatkan kebutuhan makan secara berlebihan yang menimbulkan obesitas.

Di pondok pesantren Roudlatul Qur'an dikota Metro siswi pondok diberikan makan dari asrama tiga kali dalam sehari yaitu makan pagi, makan siang dan makan malam. Selain makan dari pondok siswi pondok diberikan kebebasan untuk jajan diluar pondok sehingga kebutuhan akan gizi terpenuhi terbukti dengan hasil pemeriksaan $\mathrm{Hb}$ rata-rata di atas normal (12gr\%) sebanyak $99 \%$.

Sejalan dengan penelitian yang dilakukan Setiawan (2009) dengan judul Gambaran Anemia dan Intelligence Quotient (IQ) Pada Santri Putri Pondok pesantren Imam Syuhodo Kecamatan Polokarto Kabupaten Sukoharjo dengan sampel yang diambil sejumlah 56 siswi, yang diperoleh dengan menggunakan teknik systematic random sampling Instrumen. Data penelitian ini diperoleh dari data primer dan data sekunder. Data primer diperoleh melalui pemeriksaan kadar $\mathrm{Hb}$. Data sekunder diperoleh melalui tes IQ Standard Progessive Matrices (SPM). Hasil penelitian angka rata-rata hemoglobin adalah $14,18 \mathrm{~g} / \mathrm{dL}$.

\section{Rata-Rata Kadar Hb Remaja Putri Sesudah Pemberian Paket Menu Sehat}

Dari tabel 1 dapat diketahui bahwa ratarata kadar Hb Remaja Putri di Pondok Pesantren Roudlatul Qur'an di kota Metro sesudah pemberian paket menu sehat dengan Mean 14,76 dan $9,9 \mathrm{gr} \% \mathrm{Hb}$ terendah dan $17,6 \mathrm{gr} \% \mathrm{Hb}$ tertinggi dengan standar deviasi 1,37 sedangkan pada kelompok kontrol rata-rata kadar $\mathrm{Hb}$ sesudah intervensi terendah adalah $11,0 \mathrm{gr} \%$ dan tertinggi adalah $15,4 \mathrm{gr} \%$.

Pada penelitian ini didapat nilai kadar $\mathrm{Hb}$ setelah diberi perlakuan dengan menggunakan paket menu sehat selama 14 hari terjadi kenaikan kadar $\mathrm{Hb}$ Remaja Putri di Pondok Pesantren Roudlatul Qur'an di kota 
Metro yang sebelum diberikan intervensi ratarata Hbnya adalah $14,21 \mathrm{gr} \%$ dan setelah diberi perlakuan paket menu sehat rata-rata $\mathrm{Hb}$ naik menjadi 14,76 gr\%.

Paket Menu Sehat adalah menu yang disusun dengan gizi seimbang dan tidak mengandung zat-zat gizi yang berbahaya dengan jumlah sesuai dengan kebutuhan remaja putri. Sejalan dengan teori Kementerian Kesehatan RI (2014) Gizi Seimbang adalah Susunan pangan sehari-hari yang mengandung zat gizi dalam jenis dan jumlah yang sesuai dengan kebutuhan tubuh, dengan memperhatikan prinsip keanekaragaman pangan, aktivitas fisik, perilaku hidup bersih dan mempertahankan berat badan normal untuk mencegah masalah gizi.

Hasil penelitian dengan pemberian paket menu sehat yang diberikan pada Remaja Putri di Pondok Pesantren Roudlatul Qur'an di kota Metro terdapat beberapa orang yang kadar Hbnya turun yaitu lima orang mengalami penurunan kadar $\mathrm{Hb}$ dikarenakan mengalami haid pada saat intervensi berlangsung. Hal ini dikarenakan pada saat menstruasi banyak mengeluarkan darah sehingga $\mathrm{Hb}$ menjadi turun. Menurut Proverawati (2011) remaja putri yang telah memasuki masa pubertas dan mulai menstruasi tiap bulannya lebih mudah menderita anemi dibandingkan dengan remaja putra. Wanita dan remaja putri membutuhkan zat besi dua kali lipat lebih banyak dari pada pria atau remaja putra karena mengalami haid dan banyak mengeluarkan darah waktu melahirkan.

Sejalan dengan penelitian yang dilakukan Prastika (2011) dengan judul Hubungan Lama Menstruasi terhadap kadar Haemoglobin pada Remaja siswi SMA 1 Wonosari, jenis penelitian observasional analitik dengan pendekatan crosssectional, sampel diambil sebanyak 30 siswi SMA Negeri 1 Wonosari kelas X menggunakan teknik quota sampling. Analisis uji statistik Hasil Kali Product Momen dari Pearson dengan menggunakan predictive Analytics SoftWare (PASW) statistics 18. Berdasarkan analisis menggunakan Hasil Kali Product-Momen dari Pearson didapatkan nilai p sebesar $0,000(<0,05)$ dan r-0,624 $(>0,361)$. Dengan demikian dapat diambil kesimpulan terdapat hubungan yang negatip dan dignifikan antara lama menstruasi terhadap kadar haemoglobin pada remaja siswi SMA Negeri 1 Wonosari.

\section{Pengaruh Pemberian Paket Menu Sehat terhadap Peningkatan Kadar Hb}

Dari tabel 2 terlihat bahwa rata-rata kadar $\mathrm{Hb}$ pada 30 responden pada kelompok intervensi setelah pemberian Paket Menu Sehat didapat rata-rata nilai kadar $\mathrm{Hb}$ 14,76gr\% dengan standar deviasi 1,37. Hasil uji statistik nilai $p$ value $=0,000$ yang artinya ada pengaruh pemberian Paket Menu Sehat di Pondok Pesantren Roudlatul Qur'an di kota Metro Tahun 2018. Kenaikan kadar $\mathrm{Hb}$ menurut peneliti disebabkan karena beragamnya makanan yang dikonsumsi selama empat belas hari.

Faktor yang mempengaruhi kadar hemoglobin $(\mathrm{Hb})$ salah satunya adalah kecukupan zat besi dalam tubuh. Zat besi dibutuhkan untuk memproduksi hemoglobin juga merupakan mikronutrien essensial dalam memproduksi hemoglobin. Fungsi hemoglobin adalah mengangkut oksigen dari paru-paru dan dalam peredaran darah untuk dibawa ke jaringan Tarwoto (2007). Kecukupan zat besi yang dalam hal ini didapat dari makanan dengan pola makan yang beragam seperti yang dikemukan oleh Umiyarni, (2018) yaitu semakin kecil ukuran tumpeng gizi seimbang berarti pangan pada lapisan atas seperti gula, garam dan lemak perlu dibatasi sehingga kelompok pangan yang dianjurkan kelompok sayuran untuk remaja. Perlu diketahui bahwa daya serap besi yang berasal dari pangan nabati jauh lebih rendah dibandingkan daya serap besi dari pangan hewani.

Dengan Paket Menu Sehat yang terdiri dari Nasi, sayuran, Lauk pauk dan buah adalah makanan yang beragam dalam sehari maka kadar $\mathrm{Hb}$ pada remaja putri di Pondok Pesantren Roudlatul Qur'an dikota Metro Tahun 2018 meningkat sehingga dapat dikatakan ada pengaruh pemberian paket menu sehat terhadap peningkatan kadar $\mathrm{Hb}$.

Menurut Almatsier (2005) Menu seimbang adalah susunan makanan yang dimakan oleh seseorang untuk sekali makan atau untuk seharihari. Kata "menu" biasa diartikan "hidangan". Menu seimbang adalah menu yang terdiri dari beraneka ragam makanan dalam jumlah dan proporsi yang sesuai, sehingga memenuhi kebutuhan gizi seseorang guna pemeliharaan dan perbaikan sel-sel tubuh dan proses kehidupan serta pertumbuhan dan perkembangan.

Sejalan dengan penelitian yang dilakukan Muchlisa,dkk, (2013) tentang Hubungan asupan zat gizi dengan status gizi pada remaja putri di Fakultas Kesehatan Masyarakat di Universitas Hasanuddin Makasar. Penelitian ini bertujuan untuk mengetahui hubungan antara asupan zat gizi dengan status gizi pada remaja putri di FKM UNHAS Makassar. Jenis penelitian yang digunakan adalah survei analitik dengan desain cross sectional. Populasi dalam penelitian ini 
adalah semua mahasiswi FKM UNHAS angkatan 2012 yang berusia 18-20 tahun yang berjumlah 189 orang. Teknik pengambilan sampel yang digunakan adalah purposive sampling sehingga diperoleh 160 sampel. Pengolahan dan analisis data pada penelitian ini adalah univariat dan bivariat. Hasil dari analisis diketahui bahwa asupan energi dan zat gizi makro responden sudah mencukupi kebutuhan sedangkan untuk asupan zat gizi mikro, masih kurang. Status gizi responden tergolong normal baik berdasarkan IMT maupun LILA. Hasil dari uji korelasi Spearman, diketahui bahwa terdapat hubungan yang signifikan antara energi ( $p$ IMT dan LILA $=0,000)$, protein ( $p$ IMT dan LILA $=0,000$ ), lemak $(p \mathrm{IMT}=0,002$ dan $p$ LILA $=0,000)$, karbohidrat ( $p$ IMT dan LILA $=0,000$ ), zat besi ( $p \mathrm{IMT}=0,001$ dan $p$ LILA $=0,000)$, dan seng ( $p$ IMT dan LILA $=0,000$ ) dengan status gizi berdasarkan IMT dan LILA. Para remaja khususnya remaja putri disarankan mengkonsumsi beraneka ragam makanan agar kekurangan zat gizi pada jenis makanan yang satu akan dilengkapi oleh zat gizi dari makanan yang lainnya.

\section{Rata-Rata Kadar Hb Sebelum dan Sesudah Pemberian Paket Menu Sehat}

Pada penelitian ini berdasarkan gambar Histogram 1 terlihat hampir semua kadar $\mathrm{Hb}$ responden terjadi peningkatan $\mathrm{Hb}$ rata-rata $0,45 \mathrm{gr} \%$. Menurut pendapat peneliti hal ini terjadi dikarenakan beberapa faktor yang mempengaruhi diantaranya adalah

1. Distribusi responden yang tidak merata dikarenakan adanya kadar hb responden sebelum intervensi terlihat diatas normal $(14 \mathrm{gr} \%)$ sebanyak $53,3 \%$.

2. Alat yang digunakan untuk melakukan pemeriksaan kadar $\mathrm{Hb}$ pada responden adalah Haemo Cek tanpa membuat perbandingan dengan metode pemeriksaan $\mathrm{Hb}$ yang lain.

3. Paket Menu Makanan Sehat yang diberikan kepada responden terbatas hanya dua minggu.

Sementara itu pada kelompok program pondok tidak semua mengalami kenaikan kadar $\mathrm{Hb}$ dari 30 responden hanya 8 responden $(26,6 \%)$ yang mengalami kenaikan kadar $\mathrm{Hb}$. Menurut peneliti responden yang tidak mengalami kenaikan kadar $\mathrm{Hb}$ dikarenakan kurang beragamnya asupan makanan sehingga kadar $\mathrm{Hb}$ tidak meningkat, bahwa Pola makan yang kurang beragam, seperti menu yang terdiri dari nasi dan kacang-kacangan saja turut menunjang kurangnya asupan besi bagi tubuh sehingga perlu pondok pesantren membuat menu yang beragam.

\section{SIMPULAN}

Paket menu sehat berpengaruh bagi peningkatan kadar $\mathrm{Hb}$ remaja putri di Pondok Pesantren Roudlatul Qur'an di Kota Metro.

Proverawati, Atikah. (2011). Anemia dan Anemia kehamilan. Yogyakarta: Nuha Medika.

Prastika, Dwi Andang. (2011). Hubungan Lama Menstruasi terhadap kadar Haemoglobin pada Remaja siswi SMA 1 Wonosari. (Karya Tulis Ilmiah, Universitas Sebelas Maret). Surakarta.

eprints.uns.ac.id/4881/1/210451511201107 561.pdf

Listiana, A. (2016). Analisis faktor-faktor yang berhubungan dengan kejadian anemia gizi besi pada remaja putri di SMKN 1 Terbanggi Besar Lampung Tengah. Jurnal Kesehatan, 7(3), 455-469.

Manuaba. (2010). Ilmu kebidanan Penyakit Kandungan dan KB. Jakarta: EGC.

Martini, M. (2016). Faktor-faktor yang Berhubungan dengan Kejadian Anemia pada Remaja Putri di MAN 1 Metro. Jurnal Kesehatan Metro Sai Wawai, 8(1), 1-7.
Riset Kesehatan Dasar. (2013). Riskesdas 2013. Jakarta: Badan Litbang Kesehatan.

Suryani Destri,Hafiani Riska, Junita R. (2016). Jurnal Kesehatan Masyarakat Andalas, Volume 10 No 1.

Sukmawati. (2011). Faktor-faktor yang Berhubungan dengan Kejadian Anemia pada Remaja Putri Kelas VII dan VIII di SMP Metro Kibang Lampung Timur Tahun 2011. KTI. Tidak Dipublikasikan.

Setiawan, Sigit. (2009). Gambaran Anemia dan 
Intelligence quotient (iq) pada santri putri pondok pesantren imam syuhodo kecamatan polokarto kabupaten sukoharjo. (Skripsi, Universitas Muhammadiyah Surakarta).

Umiyarni dyah Purnamawati. (2018). Panduan Gizi dan Kesehatan Anak Sekolah, Yogyakarta: Andi Offset.
Tarwoto dan Wasnidar. (2007). Anemia Pada Ibu Hamil Konsep dan Penatalaksanaan. Jakarta: Trans Info Media.

WHO. 2001. Iron Deficiency Anemia assessment, Prevention and Control. A guide for Programe Manager.

Wiwik, H., \& Sulistyo, H. (2008). Asuhan keperawatan pada klien dengan gangguan sistem hematologi. Jakarta: Salemba. 